\title{
Response to kisspeptin and gonadotropin-releasing hormone agonist administration in Holstein-Friesian dairy heifers with positive or negative genetic merit for fertility traits
}

\author{
H. E. Flay, ${ }^{1} \odot$ C. B. Reed, ${ }^{1} \odot$ B. Kuhn-Sherlock, ${ }^{1} \odot$ C. V. C. Phyn, ${ }^{1} \odot$ C. R. Burke, ${ }^{1} \odot$ S. Meier, ${ }^{1 *} \odot$ \\ and I. J. Clarke ${ }^{2}$ () \\ ${ }^{1}$ DairyNZ Limited, Private Bag 3221, Hamilton, 3240, New Zealand \\ ${ }^{2}$ Faculty of Veterinary and Agricultural Sciences, University of Melbourne, Parkville, VIC 3010, Australia
}

\begin{abstract}
Previous research has identified that Holstein-Friesian dairy heifers with positive (POS) genetic merit for fertility traits (FertBV) reach puberty earlier than heifers with negative (NEG) FertBV. The hypothalamuspituitary-gonadal (HPG) axis is functional in heifers before the onset of puberty, with increased LH release evident as heifers progress toward puberty. We investigated the functionality of the HPG axis in peripubertal Holstein-Friesian dairy heifers with divergent POS or NEG FertBV, hypothesizing that the earlier puberty onset of POS heifers is associated with earlier activation of the HPG axis than in NEG heifers. In experiment 1, we tested the dose responsiveness of POS heifers to an intravenous injection of either kisspeptin [Kiss; 2, 4, or $8 \mu \mathrm{g} / \mathrm{kg}$ of body weight $(\mathrm{BW}) ; \mathrm{n}=3$ per dose] or a GnRH agonist (buserelin; 5, 10, or $20 \mathrm{ng} / \mathrm{kg}$ of BW; n $=3$ per dose). The use of these 2 agonists investigates the status of the HPG axis in both the hypothalamus (Kiss) and pituitary (buserelin) glands. Doses of $4 \mu \mathrm{g} /$ $\mathrm{kg} \mathrm{BW}$ of Kiss and $10 \mathrm{ng} / \mathrm{kg}$ BW of buserelin produced submaximal LH responses and were used in experiment 2 , in which previously unused POS $(\mathrm{n}=22)$ and NEG $(\mathrm{n}=18)$ FertBV heifers were challenged with both agonists at 10 and 12 mo of age in a partial crossover design. Heifers were randomly allocated to treatment groups, balanced for age and BW. The LH response to buserelin was greater in POS heifers than NEG heifers at $10 \mathrm{mo}$ of age, with no difference in response at 12 mo. The FSH response to buserelin and the $\mathrm{LH}$ and FSH responses to Kiss did not differ between the POS and NEG heifers at either age. These results indicate an association between divergent genetic merit for fertility and the LH release to buserelin at 10 mo of age, supporting the hypothesis that gonadotropin respon-
\end{abstract}

Received October 7, 2021.

Accepted December 13, 2021

*Corresponding author: Susanne.Meier@dairynz.co.nz siveness to a GnRH agonist is more advanced in POS heifers than in NEG heifers.

Key words: luteinizing hormone, puberty, hypothalamus-pituitary-gonadal axis

\section{INTRODUCTION}

Dairy cow fertility is a major determinant of farm profitability in dairy systems that are dependent on seasonal calving (Esslemont et al., 2001; Shalloo et al., 2014; Kerslake et al., 2018). Nevertheless, global declines have occurred in both phenotypic and genetic fertility of dairy cows (Berry et al., 2014; Pryce et al., 2014). Many dairy sectors have responded with an increased emphasis on functional, health, and fertility traits in genetic evaluation, in an effort to reduce or reverse this trend (Egger-Danner et al., 2015). However, improving the rate of genetic gain in fertility is a challenge because of the low heritability of relevant traits and the greater focus on production traits within breeding objectives (von Keyserlingk et al., 2013). An increased rate of genetic gain for fertility could be achieved by incorporating traits into the calculation of genetic merit that (1) positively correlate with fertility, (2) have a greater heritability than factors currently considered, and (3) can be evaluated early in life. Previous work has indicated that age at puberty is associated with genetic merit for fertility traits and may be a useful phenotype for genetic selection (Meier et al., 2021b).

Reproduction, including the onset of puberty, is driven by the brain, whereby $\mathrm{GnRH}$ is secreted from the hypothalamus in a pulsatile fashion to stimulate the synthesis and secretion of gonadotrophins from the anterior pituitary gland (Clarke et al., 2012; Clarke, 2014). In turn, LH and FSH, secreted from the pituitary gonadotropes, act upon the gonads and cause secretion of sex steroids and protein hormones, which exert feedback control on both the brain and the pituitary gland, completing the closed loop of the hypothalamuspituitary-gonadal (HPG) axis. Sex steroids have cyclic 
negative and positive feedback action in the female, depending upon the estrous cycle stage. The GnRH cells do not express sex steroid receptors (Herbison et al., 1993; Lehman and Karsch, 1993), but the effects of sex steroids on $\mathrm{GnRH}$ secretion occur through various cell types in the brain, the most important being the kisspeptin (Kiss) cells (Clarke, 2011; Clarke et al., 2012). The Kiss cells express steroid receptors in the ewe (Franceschini et al., 2006) and mediate the feedback effects of gonadal steroids, thus regulating the pulsatile secretion of GnRH in ungulates (Smith et al., 2011; Ezzat et al., 2015).

In all species examined, including cattle, systemic administration of either GnRH or Kiss stimulates LH and FSH release (Nakada et al., 2002; Leonardi et al., 2018; Macedo et al., 2019). Kiss has been recognized to be essential for the regulation of reproduction and puberty onset (Scott et al., 2018). Whereas GnRH acts on the pituitary gonadotropes, studies in sheep indicate that Kiss acts at the level of the median eminence to stimulate pulsatile GnRH secretion (Ezzat et al., 2015). The LH response to GnRH stimulation occurs in calves as young as 1 mo of age (Nakada et al., 2002), and the LH response to Kiss stimulation occurs by at least 4 to 5 mo of age (Ezzat Ahmed et al., 2009; Alamilla Rodríguez et al., 2017). Thus, the HPG axis starts to become functional in prepubertal heifers from a relatively young age, and as the heifer progresses toward puberty, LH secretion in response to $\mathrm{GnRH}$ or Kiss stimulation increases (Nakada et al., 2002; Alamilla Rodríguez et al., 2017).

Recently, Meier et al. (2021b) reported that heifers with extreme positive (POS) genetic merit for fertility traits reached puberty $27 \mathrm{~d}$ earlier and at a BW 20 $\mathrm{kg}$ lighter than heifers with extreme negative (NEG) genetic merit for fertility traits. The POS cows displayed better reproductive performance during their first and second lactations, which was driven by their greater propensity to resume ovarian cyclicity postpartum (Meier et al., 2021a). As puberty is a moderately heritable trait (Mialon et al., 2000; Morris et al., 2000; Morris and Hickey, 2004; Johnston et al., 2009) that can be measured earlier in life, a greater understanding of the mechanisms by which genetic selection can drive earlier puberty will assist breeding programs for improved fertility. Given that the HPG axis is activated in the months before puberty, we hypothesized that the HPG axis of POS heifers is more active than that of NEG heifers in the peripubertal period. To test this hypothesis, we administered a GnRH agonist (buserelin) and Kiss to POS and NEG heifers at 10 and 12 mo of age and measured plasma LH and FSH responses. The use of these 2 agonists investigates the status of the HPG axis in both the hypothalamus (Kiss) and the pituitary (buserelin) glands.

\section{MATERIALS AND METHODS}

The experiments were undertaken on the DairyNZ Lye Farm, Hamilton, New Zealand $\left(37.78^{\circ} \mathrm{S}, 175.28^{\circ} \mathrm{E}\right)$ between April and September 2019, with prior approval of the Ruakura Animal Ethics Committee (no. 14654) in accordance with the New Zealand Animal Welfare Act (Ministry for Primary Industries, 1999). The Agricultural Compounds and Veterinary Medicines Group, Ministry for Primary Industries, approved the use of bovine Kiss (Res. Approval Certificate no. A011668), which was synthesized by Mimotopes (Melbourne, Australia). A single peak on HPLC confirmed purity at $>97 \%$. Mass spectrometry revealed a mass ion of 1,318.95 g/mol, confirming structure and composition as bovine Kiss: H-YNWNSFGLRY-NH $\mathrm{NH}_{2}$. Buserelin acetate (Receptal, MSD Animal Health) was used as a GnRH receptor agonist.

\section{Experimental Animals}

The Holstein-Friesian dairy heifers used were born between July and September 2018, as progeny of the POS and NEG fertility breeding value (FertBV) population previously reported by Meier et al. (2021b). New Zealand's FertBV is a predictor for genetic merit for fertility traits, largely based on the binary phenotype of re-calving in the first $42 \mathrm{~d}$ of the calving season (DairyNZ, 2016). The POS heifers $(\mathrm{n}=40)$ were born to POS cows sired by bulls with POS FertBV. Conversely, the NEG heifers $(n=18)$ were born to NEG cows sired by bulls with NEG FertBV.

\section{Experiment 1. Dose-Response Relationships for Kisspeptin and Buserelin Challenges}

In experiment 1 , we used a subset of 18 POS heifers to identify doses of Kiss and buserelin that produced desirable, submaximal plasma LH and FSH responses. Mean $( \pm$ SEM) age of these heifers was $267 \pm 0.6 \mathrm{~d}(\sim 9$ mo of age), BW was $180 \pm 3.9 \mathrm{~kg}$, and FertBV was 3.1 $\pm 0.17 \%$ (FertBV data accessed through New Zealand Animal Evaluation Limited, personal communication). The experimental design is presented in Figure 1A. Experimental day was defined as the day relative to the day of Kiss and buserelin infusion (d 0).

Luteal activity of the heifers was assessed by measurement of plasma progesterone (P4) concentrations in blood samples taken from the coccygeal vessel weekly from $d-7$ to $d 21$. After collection of the blood sample 
for P4 analysis on $\mathrm{d}-7$, the heifers were administered 2 intravaginal P4 releasing devices designed for use in sheep and goats [Eazi-Breed CIDR (controlled intravaginal delivery release) Sheep and Goat Devices, Zoetis], to prevent possible ovulations and ensure an equivalent P4 status during the experimental period. These devices were removed at completion of the intensive blood sampling period following Kiss or buserelin infusion on d 0, heifers received an i.m. injection of 250 $\mu \mathrm{g}$ of cloprostenol (Ovuprost, Bayer) to induce luteolysis in any heifers with a functional corpus luteum.

An indwelling cannula was placed into a jugular vein of every heifer on $\mathrm{d}-4$, for intensive blood sampling.
On $\mathrm{d}-2$, the heifers received a control vehicle injection $(2 \mathrm{~mL})$ of normal saline infused through the cannula, with blood samples collected at $-60,-30,0,+15$, $+30,+45,+60,+90,+120,+150,+180$, and +210 min pre- and postinjection (Figure 1A). This provided an estimate of a possible placebo effect. On $\mathrm{d} 0$, the heifers received either Kiss or buserelin injections via the cannulas. Doses were 2, 4, or $8 \mu \mathrm{g} / \mathrm{kg}$ of BW for Kiss and 5,10 , or $20 \mathrm{ng} / \mathrm{kg}$ of $\mathrm{BW}$ for buserelin $(\mathrm{n}=$ 3 randomly selected heifers per dose, balanced for age and BW). These doses were based on those used in previous studies (Nakada et al., 2002; Kadokawa et al., 2008; Leonardi et al., 2018; Macedo et al., 2019). Blood
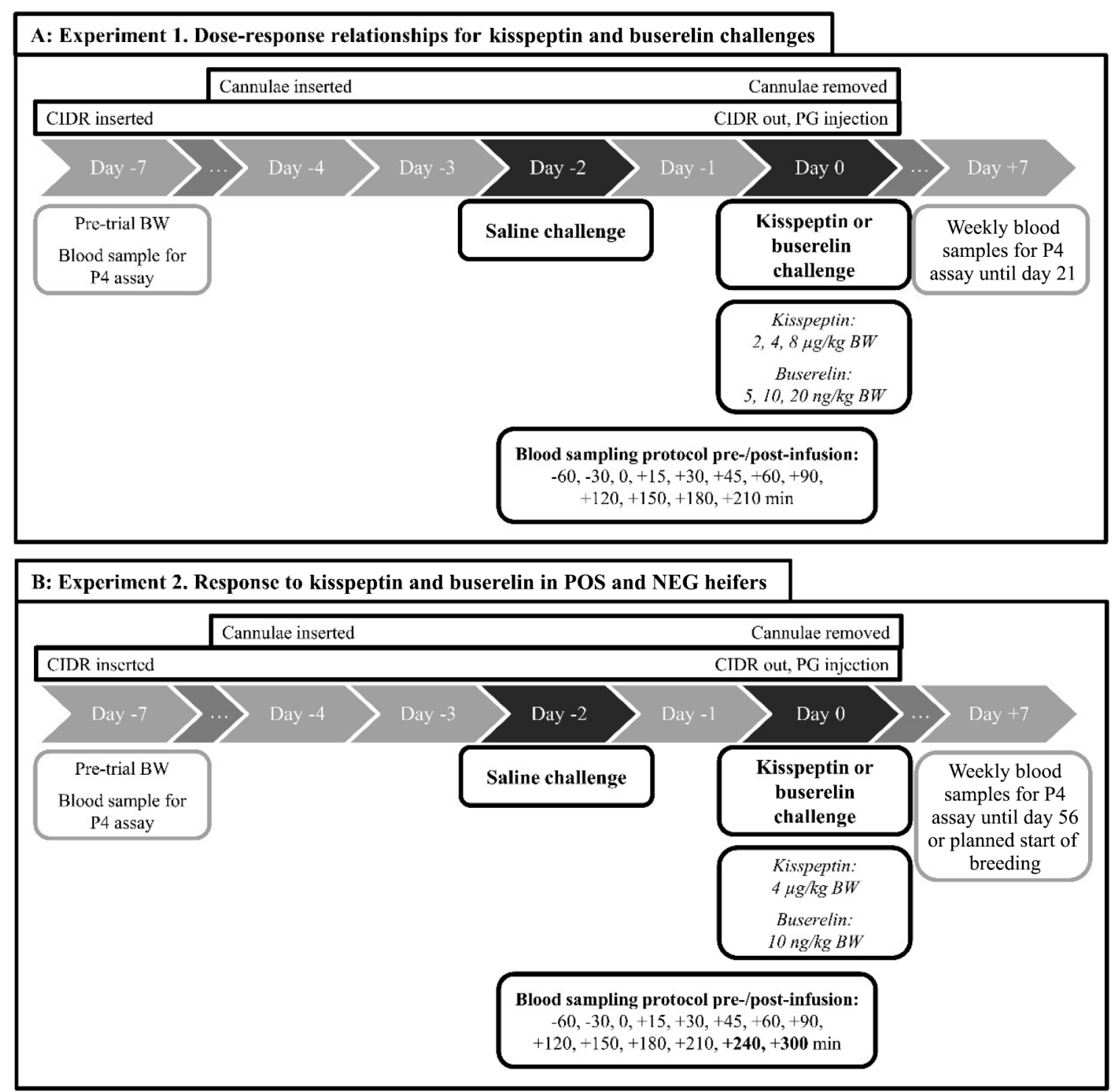

Figure 1. Experimental schedules for intensive sampling periods in experiment 1 (A) and experiment 2 (B). In experiment 2 , this intensive sampling period was repeated at 10 and $12 \mathrm{mo}$ of age. $\mathrm{CIDR}=$ controlled intravaginal delivery release; $\mathrm{PG}=$ prostaglandin (cloprostenol); $\mathrm{P} 4$ $=$ progesterone. 
samples were collected at $-60,-30,0,+15,+30,+45$, $+60,+90,+120,+150,+180$, and +210 min relative to injection (Figure 1A). The cannulas were removed at completion of the intensive blood sampling period following Kiss or buserelin injections.

Blood samples were collected into heparinized tubes and held on ice before centrifugation $(1,840 \times g$ for 12 min) at $4^{\circ} \mathrm{C}$ and harvest of plasma. The plasma samples were stored at $-20^{\circ} \mathrm{C}$ until assayed to measure $\mathrm{LH}$ and FSH.

\section{Experiment 2. Response to Kisspeptin and Buserelin in POS and NEG Heifers}

A total of 22 POS and 18 NEG FertBV heifers were assigned to groups for either Kiss or buserelin challenge, balanced for age and BW. The experimental procedure is outlined in Figure 1B. The mean $( \pm \mathrm{SEM})$ FertBV for the POS heifers was $3.6 \pm 0.15 \%$, and for the NEG heifers it was $-6.0 \pm 0.26 \%$ (data accessed through New Zealand Animal Evaluation Limited, personal communication). The heifers were trialed in 3 cohorts based on age, to ensure less variation in the individual ages of the animals at time of challenge. The experiment commenced for each cohort when the average age was 10 mo (mean \pm SEM; $311 \pm 0.8 \mathrm{~d}$ ) and was repeated at $12 \mathrm{mo}$ of age $(360 \pm 0.8 \mathrm{~d}$; Table 1$)$. The POS and NEG heifers were all reared together in the same environment and had achieved similar BW, height, length, and BCS at the time of the challenges (Table 1). Based on the results of experiment 1, the dose of Kiss was 4 $\mu \mathrm{g} / \mathrm{kg}$ of BW and the dose of buserelin was $10 \mathrm{ng} / \mathrm{kg}$ of BW. Half of the heifers that received Kiss at 10 mo of age were randomly assigned to a buserelin challenge at 12 mo of age, and vice versa.

The experimental design was similar to that for experiment 1 , but additional blood samples were taken at +240 and +300 min postinjection for all challenges (saline, Kiss, and buserelin), based on the observations of experiment 1 . The blood samples for both the saline and agonist challenges were assayed for LH analysis, but only the agonist challenge blood samples were assayed for FSH analysis. Coccygeal vessel blood sampling for plasma $\mathrm{P} 4$ concentrations started at $\mathrm{d}-7$ relative to the 10-mo challenge and continued weekly until d 56 after the 12-mo challenge, or until the planned start of breeding (at $\sim 13-14$ mo of age), whichever came first for an individual heifer.

\section{Hormone Assays}

Validation of the measurement of LH and FSH in cows using radioassays has been reported previously (Otto et al., 2014). Plasma LH concentrations were measured in 5 assays using National Institutes of Health, AFP-11118 as a standard. The assays had an average sensitivity of $0.06 \mathrm{ng} / \mathrm{mL}$, and the intra- and interassay coefficients of variation were $<10 \%$. Plasma FSH concentrations were measured in 4 assays using National Institutes of Health, AFP-9294C as a standard. The assays had an average sensitivity of $0.05 \mathrm{ng} / \mathrm{mL}$, and the intra- and interassay coefficients of variation were $<10 \%$.

A commercial double antibody radioimmunoassay kit (ImmuChem Progesterone Double Antibody RIA, MP Diagnostics) was used to determine plasma P4 concentrations in accordance with the manufacturer's instructions but with the reagents and samples or standards halved in volume. The intra- and interassay $(\mathrm{n}=11$ assays) coefficients of variation were $12.5 \%$ and $14.6 \%$, respectively, and the minimal detectable concentration was $0.3 \mathrm{ng} / \mathrm{mL}$. Heifers were classified as cycling when $\mathrm{P} 4$ concentrations were greater than $1 \mathrm{ng} / \mathrm{mL}$ (Meier et al., 2021b), except when CIDR were inserted.

\section{Statistical Analysis}

The number of heifers included in experiment 2 was limited by the availability of NEG FertBV heifers from the parent experiment. A retrospective sample size calculation was undertaken, which identified that with

Table 1. Experiment 2: mean ( \pm SEM) age, BW, height, ${ }^{1}$ length,${ }^{2}$ and BCS of positive (POS) and negative (NEG) fertility breeding value (FertBV) heifers for each treatment group receiving either kisspeptin or buserelin challenge at 10 and 12 mo of age

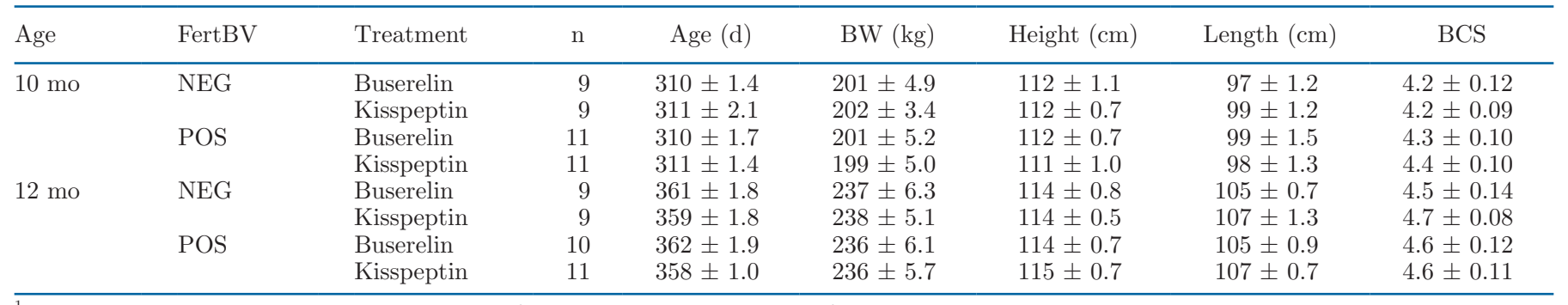

${ }^{1}$ Height was measured as the vertical distance from the ground to the top of the withers.

${ }^{2}$ Length was measured as the horizontal distance between the bottom of the pin bones to the top of the withers. 
10 animals in each FertBV group a difference in the gonadotropin responsiveness to a $\mathrm{GnRH}$ agonist of 1.4 standard deviations was detectable with $80 \%$ power and $5 \%$ significance.

The statistical analyses were performed using SAS 9.4 (SAS Institute Inc.). Data were $\log _{10}$ transformed if required to achieve homogeneity of variance. Significance was declared if $P \leq 0.05$. Data are presented as least squares means \pm standard error of the mean or standard error of the difference.

One freemartin heifer (POS FertBV) was eliminated from experiment 1 (Kiss, $8 \mu \mathrm{g} / \mathrm{kg} \mathrm{BW}$ ), and one POS FertBV heifer was removed from experiment 2 before the 12-mo challenge due to ill health unrelated to the trial.

The postinjection LH and FSH results were corrected for pretreatment baseline concentrations by subtracting the average preinjection $(-60,-30$, and $0 \mathrm{~min}) \mathrm{LH}$ or FSH concentrations. The following variables were calculated for responses to agonists:

- Cmax: the peak concentration of LH or FSH

- Tmax: the time from injection to peak LH or FSH concentration

- AUC: the total area under the curve postinjection, calculated using the trapezoidal method

The variables Cmax, Tmax, and AUC were calculated across the entire postinjection period (experiment 1: injection to +210 min; experiment 2 : injection to +300 $\min )$. For the buserelin treatment, Cmax, Tmax, and AUC were also calculated across 2 phases to account for the releasable pool of LH and FSH released in phase 1 and mobilized gonadotropins in phase 2 (Clarke and Cummins, 1985). Timing for phase 1 was from injection to $+60 \mathrm{~min}$, and phase 2 was from +60 to $+210 \mathrm{~min}$ (experiment 1 ) or +60 to +300 min (experiment 2 ).

In experiment 1 , data from the 2 treatments (Kiss and buserelin) were analyzed separately. Dose-related effects on Cmax, Tmax, and AUC for the LH and FSH responses to buserelin and Kiss were analyzed by simple linear regression for the fixed effect of dose, across the entire postinjection period and within each phase (buserelin). Further, concentrations for each time sampling point were analyzed using a repeated-measures ANOVA (PROC MIXED). The model included dose, time, and interaction as fixed effects, and heifer as a random effect. The covariance structure was first-order autoregressive.

In experiment 2 , data from the saline challenge, the 2 treatments (Kiss and buserelin), and the 2 challenges (10 and 12 mo of age) were analyzed separately. The effects of FertBV on Cmax, Tmax, and AUC for the LH and FSH responses were analyzed using ANOVA across the entire postinjection period and within each phase (buserelin). The model included FertBV (POS vs. NEG) as the fixed effect, cohort as a blocking factor, and age at $10 \mathrm{mo}$ as a covariate. For the challenge period at 12 mo of age, treatment at 10 mo was also included in the model as a blocking factor. To analyze the concentrations for each time sampling point, a separate analysis using a mixed models approach to repeatedmeasures ANOVA was undertaken. The model included FertBV, time, and interaction as fixed effects and heifer as a random effect, as well as cohort as a blocking factor, and age at $10 \mathrm{mo}$ as a covariate. For the challenge period at 12 mo of age, treatment at 10 mo was also included in the model as a blocking factor. The covariance structure was first-order autoregressive.

In experiment 2, the plasma $\mathrm{P} 4$ concentrations sampled at $7 \mathrm{~d}$ pre- and 7,14 , and $21 \mathrm{~d}$ postchallenges were used to assess ovulatory status before and after both the 10- and 12-mo challenges. Heifers were classified as cycling when plasma P4 concentrations were greater than $1 \mathrm{ng} / \mathrm{mL}$. We used a binary logistic regression (PROC GLIMMIX) to test for the fixed effect of FertBV (POS vs. NEG), treatment (Kiss vs. buserelin), challenge period (10 vs. 12 mo of age), and pre- versus postchallenge on the percentage of heifers with luteal activity.

\section{RESULTS}

\section{Experiment 1. Dose-Response Relationships for Kisspeptin and Buserelin Challenges}

Baseline concentrations of LH and FSH following saline treatment on $\mathrm{d}-2$ are presented in Figure 2. Buserelin, administered on d 0, elicited prolonged increases in plasma LH and FSH concentrations that peaked at $\sim 125$ min postchallenge (Figure 2 ). In contrast, Kiss produced immediate but smaller, shorterlived responses that peaked at $\sim 16 \mathrm{~min}$ postchallenge for LH and FSH (Figure 2). The LH response to buserelin was biphasic, with linear dose-response relationships evident for Cmax and AUC during both the short phase 1 and the long phase 2 responses (Table 2). The dose-response to Kiss was less than that of buserelin, although a significant linear relationship for Cmax occurred for both plasma LH and FSH (Table 2). Doses of $10 \mathrm{ng} / \mathrm{kg}$ of BW for buserelin and $4 \mu \mathrm{g} / \mathrm{kg}$ of BW for Kiss were identified as being submaximal.

\section{Experiment 2. Response to Kisspeptin and Buserelin in POS and NEG Heifers}

Baseline concentrations of LH, established on $\mathrm{d}-2$ following saline treatment, were similar in POS and 

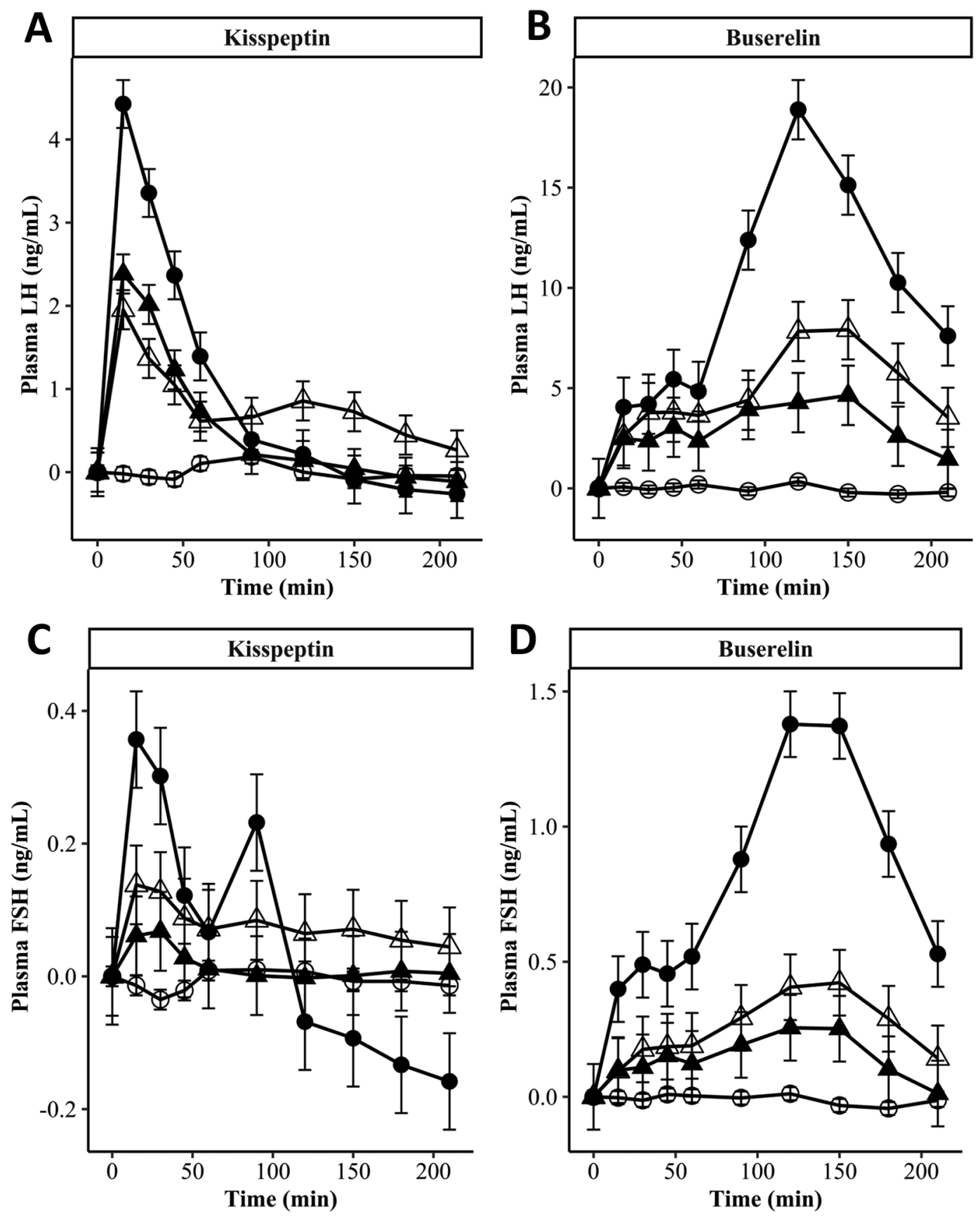

\section{Kisspeptin dose, $\mu \mathrm{g} / \mathrm{kg}$ of BW \\ $\bigcirc$ Saline $\Delta 2 \triangle 4 \bullet 8$}

\section{Buserelin dose, $\mathrm{ng} / \mathrm{kg}$ of $\mathrm{BW}$}

$\bigcirc$ Saline $\Delta 5 \Delta 10 \bullet 20$

Figure 2. Least squares means ( \pm SEM) of plasma concentrations of LH (A and B) and FSH (C and D) following i.v. injection of saline and 3 doses ( $\mathrm{n}=3$ per dose) of either kisspeptin (A and $\mathrm{C}$ ) at 2,4 , or $8 \mu \mathrm{g} / \mathrm{kg}$ of BW, or buserelin (B and D) at 5,10, or $20 \mathrm{ng} / \mathrm{kg}$ of BW in dairy heifers at 9 mo of age. The plasma LH and FSH concentrations at each time point are corrected for the individual animals' pretreatment baseline concentrations. This means that the plasma LH and FSH concentrations may fall below $0 \mathrm{ng} / \mathrm{mL}$. This is especially prevalent in panel C due to the very small scale of plasma FSH concentrations in response to kisspeptin. 
Table 2. Experiment 1: dose-response linear regression analysis for area under the curve (AUC), peak concentration (Cmax), and time from injection to peak concentration (Tmax) for the plasma concentrations of LH and FSH following i.v. injection of kisspeptin at 2, 4, or $8 \mu \mathrm{g} / \mathrm{kg}$ of BW, or buserelin at 5,10 , or $20 \mathrm{ng} / \mathrm{kg}$ of BW in dairy heifers at 9 mo of age ${ }^{1}$

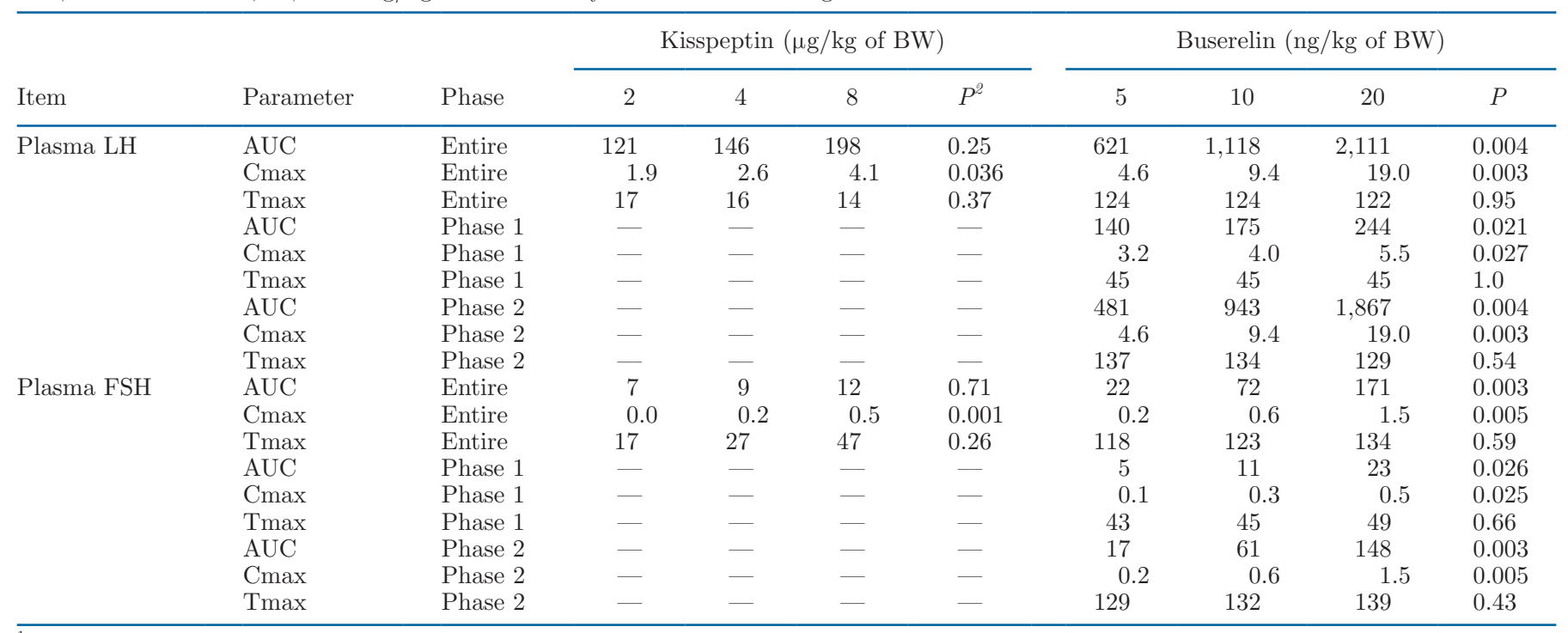

${ }^{1}$ For the buserelin challenge, results are presented for the entire response curve (injection to +210 min), phase 1 (injection to +60 min), and phase 2 ( +60 to +210 min).

${ }^{2} P$-values indicate whether there was a significant linear effect of dose.

NEG heifers, with no effect of age (Table 3). The $\mathrm{LH}$ responses to Kiss were of lesser magnitude and shorter-lived than those for buserelin (Figure 3A). No differences were detectable in the LH response to Kiss between POS and NEG heifers at either 10 or 12 mo of age (Table 3). Likewise, no significant differences occurred in the FSH response to Kiss between the POS and NEG heifers at either age (Table 4; Figure 4A).

At 10 mo of age, buserelin elicited greater $\mathrm{LH}$ responses in POS heifers than in NEG heifers (Figure $3 \mathrm{~B})$. At this time, the AUC for the entire $\mathrm{LH}$ response curve to buserelin was over $50 \%$ greater $(P=0.041)$ in the POS than the NEG heifers (Table 3). This magnitude of difference between POS and NEG heifers was similar for phase $1(P=0.066)$ and phase $2(P=0.048$; Table 3). At 10 mo of age, Cmax for the LH response to buserelin was also over $50 \%$ greater in the POS than the NEG heifers across both phases 1 and 2, approaching significance $(P=0.051 ; P=0.061)$ for both phases respectively (Table 3 ). Despite differences in both AUC and Cmax for the $\mathrm{LH}$ response to buserelin at $10 \mathrm{mo}$ of age, Tmax did not differ between POS and NEG heifers. By 12 mo of age, no significant differences in the LH response to buserelin (AUC, Cmax, or Tmax) were observed between POS and NEG heifers (Table 3; Figure 3B). At both 10 and 12 mo of age, the FSH response to buserelin (AUC, Cmax, or Tmax) did not differ between POS and NEG heifers (Table 4; Figure $4 \mathrm{~B})$.
The percentages of POS and NEG heifers within treatment group with $\mathrm{P} 4$ concentrations indicating luteal activity before and following the challenges at 10 and 12 mo of age are presented in Table 5. Blood samples taken at weekly intervals indicated that on d -7 before the 10-mo challenge none of the heifers had plasma progesterone concentrations $>1 \mathrm{ng} /$ $\mathrm{mL}$ (Table 5). The experimental protocol induced ovulation in some heifers, and many of these continued ovulating. Thus, after the 10-mo challenge, $17 \%$ $(3 / 18)$ of the NEG heifers and $64 \%(14 / 22)$ of the POS heifers displayed luteal activity indicating they had reached puberty. Before the 12-mo challenge, $22 \%$ $(4 / 18)$ of NEG heifers and $57 \%(12 / 21)$ of POS heifers had reached puberty. After the 12 -mo challenge, $94 \%(17 / 18)$ of NEG heifers and $95 \%(20 / 21)$ of POS heifers displayed luteal activity. Logistic regression to test for effects of FertBV (POS vs. NEG), treatment (Kiss vs. buserelin), challenge period (10 vs. 12 mo of age), and pre- versus postchallenge on the percentage of heifers displaying luteal activity indicated that all main effects were significant, with no significant interactive effects. The significant main effects of this logistic regression indicated that the percentage of heifers displaying luteal activity was more prevalent in POS than in NEG heifers $(58.5 \%$ vs. $18.4 \%$; $P$ $<0.001)$; greater at $12 \mathrm{mo}$ of age than at $10 \mathrm{mo}$ of age $(82.4 \%$ vs. $6.3 \% ; P<0.001)$; greater for those challenged with buserelin than for those challenged 
Table 3. Experiment 2: area under the curve (AUC), peak concentration (Cmax), and time from injection to peak concentration (Tmax) for the plasma concentrations of LH following i.v. injection of saline, kisspeptin (4 $\mu \mathrm{g} / \mathrm{kg}$ of BW), or buserelin (10 $\mathrm{ng} / \mathrm{kg}$ of BW) in dairy heifers with negative (NEG) or positive (POS) fertility breeding values (FertBV) at 10 and 12 mo of age ${ }^{1}$

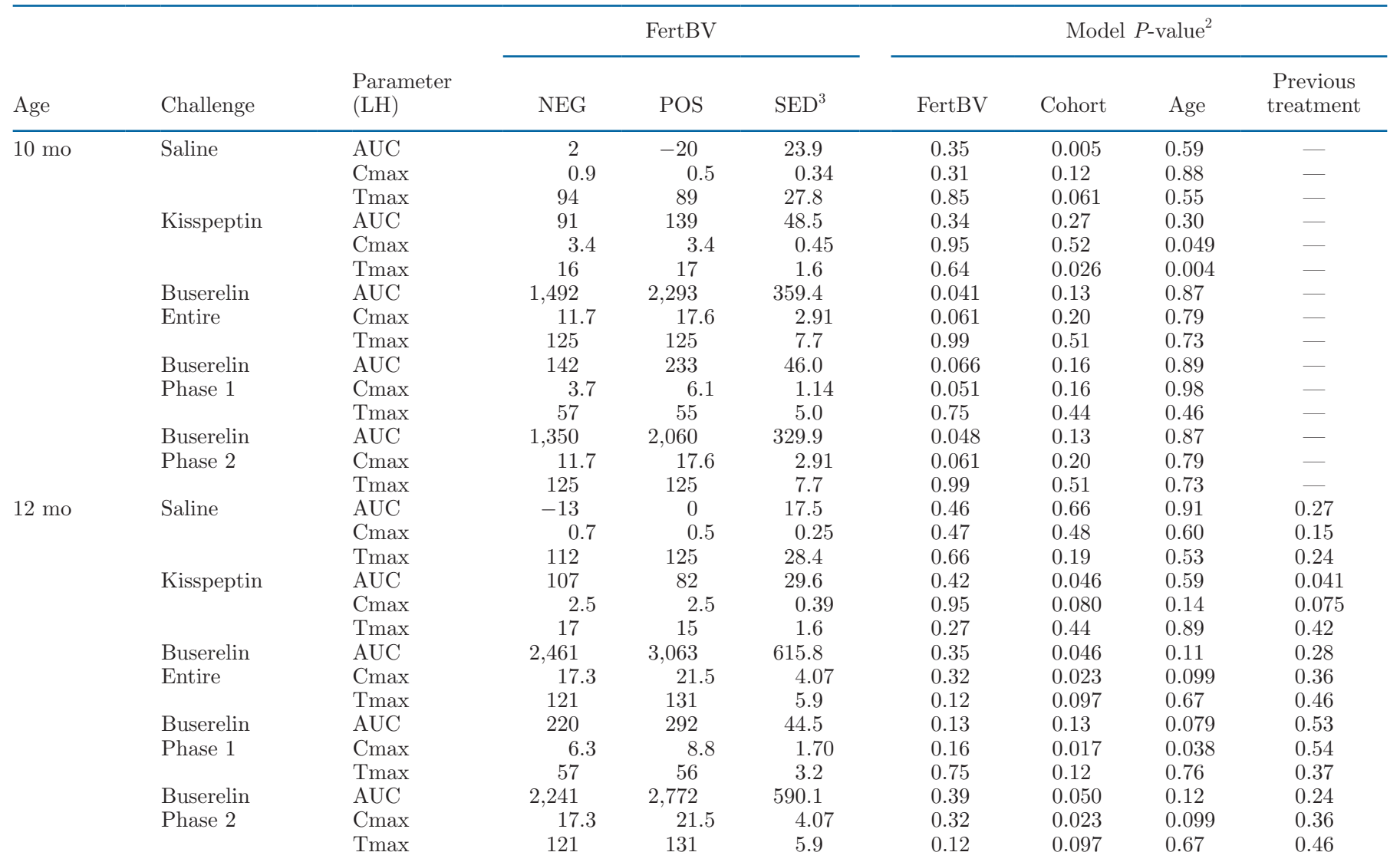

${ }^{1}$ For the buserelin challenge, results are presented for the entire response (injection to +300 min), phase 1 (injection to +60 min), and phase 2 (+60 to $+300 \mathrm{~min})$.

${ }^{2} P$-values for cohort indicate whether there was a significant effect of the cohort in which the animals were challenged. $P$-values for age indicate whether there is a significant linear effect of animals' actual age at 10 mo. $P$-values for previous treatment indicate whether the treatment the animal received at 10 mo was significant (only relevant for the 12 -mo challenge).

${ }^{3} \mathrm{SED}=$ standard error of the difference.

with Kiss $(49.4 \%$ vs. $24.5 \% ; P=0.029)$; and greater postchallenge than prechallenge $(82.7 \%$ vs. $6.2 \% ; P$ $<0.001)$.

\section{DISCUSSION}

We assessed whether the earlier onset of puberty in heifers with POS compared with NEG FertBV (Meier et al., 2021b) is associated with earlier activation of the HPG axis. This was done by challenging peripubertal heifers with either buserelin or Kiss and measuring their plasma LH and FSH responses. Our results support the hypothesis that the FertBV can influence the HPG axis of heifers. Specifically, heifers with a POS FertBV have greater LH release in response to a GnRH agonist than NEG heifers at a similar age and BW.
Our initial experiment determined a clear-cut doseresponse relationship for LH and FSH release following buserelin treatment at 9 mo of age, and a smaller, less obvious dose-response relationship for the response to Kiss. The data from experiment 1 indicated a submaximal dose for each agonist that could be used to compare POS and NEG FertBV heifers around the time of puberty in experiment 2. Consistent with the literature, we observed greater and more prolonged increases in LH and FSH concentrations following buserelin treatment than Kiss (Leonardi et al., 2018; Macedo et al., 2019). Further, the LH and FSH response to buserelin was biphasic, with phase 1 (injection to $+60 \mathrm{~min}$ ) representing the immediately releasable pool of $\mathrm{LH}$ and FSH, whereas phase $2(+60$ to $+300 \mathrm{~min})$ is the freshly mobilized and assembled LH and FSH released in re- 
sponse to buserelin stimulation (Clarke and Cummins, 1985). Our response profiles were generally consistent with those previously reported (Leonardi et al., 2018; Macedo et al., 2019).

We determined that POS FertBV heifers had greater responses to buserelin than NEG heifers before puberty (10 mo of age), whereas response to Kiss did not differ between the 2 FertBV groups. In particular, the LH responses to buserelin in POS heifers at 10 mo of age were over $50 \%$ greater overall response and peak concentration compared with NEG FertBV heifers. These results were significant or approached significance across the entire challenge period and during both phases 1 and 2 of the response. Although the exact mechanism is yet to be elucidated, the greater LH responses in POS heifers during phase 1 indicates that they had a larger immediately releasable pituitary pool of LH, possibly more GnRH receptors, or greater signal transduction
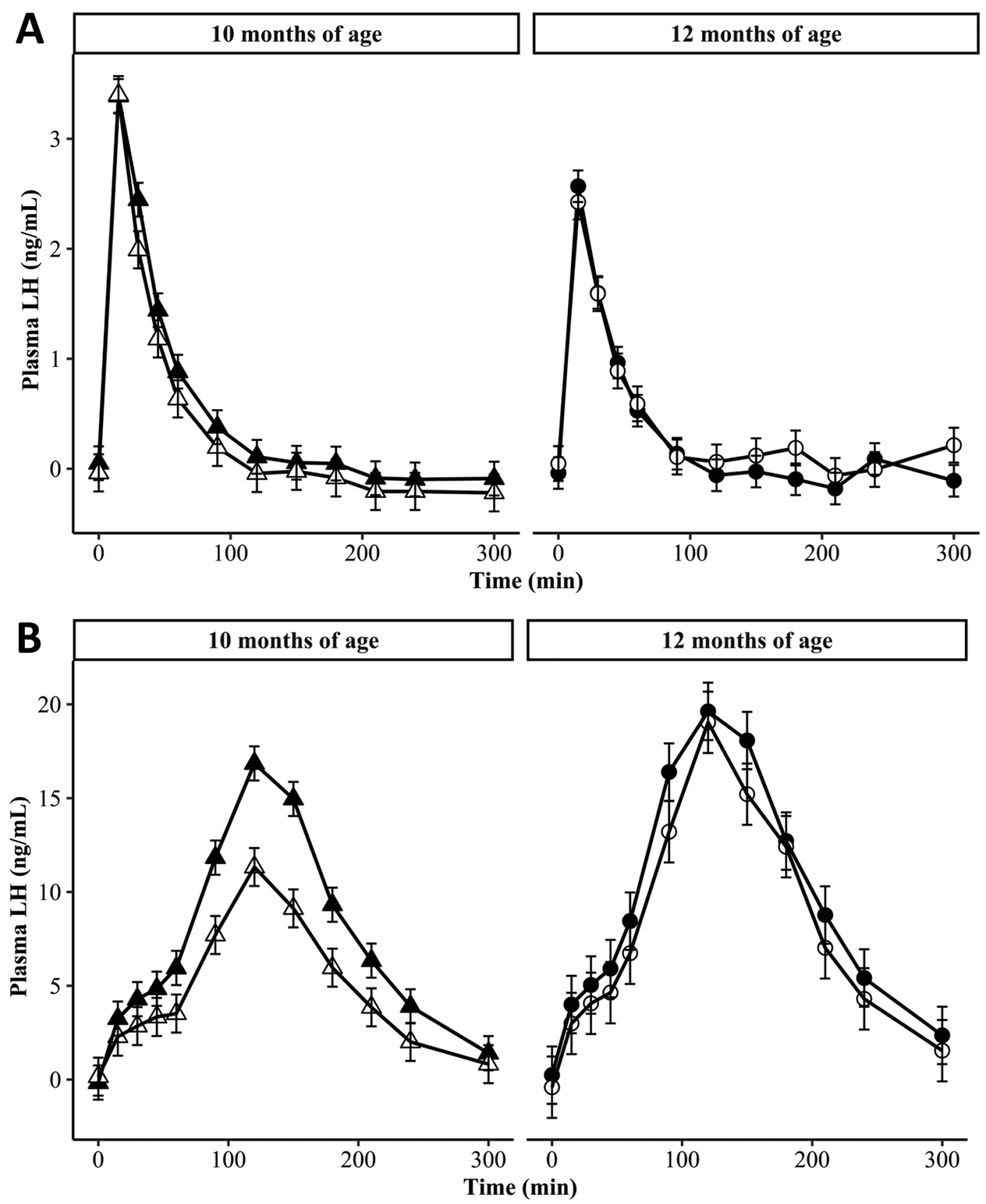

Figure 3. Least squares means $( \pm \mathrm{SEM})$ of plasma LH concentrations following i.v. injection of either $(\mathrm{A}) \mathrm{kisspeptin}(4 \mu \mathrm{g} / \mathrm{kg}$ of $\mathrm{BW})$ or $(\mathrm{B})$ buserelin $(10 \mathrm{ng} / \mathrm{kg}$ of $\mathrm{BW})$ in heifers with positive (filled) or negative (unfilled) fertility breeding values at $10(\Delta)$ and $12(\mathrm{O})$ months of age. 
to respond to the buserelin challenge. Furthermore, their greater phase 2 response indicates that they were also better able to mobilize freshly assembled LH for release. In contrast, the LH response to Kiss did not differ between the POS and NEG heifers at 10 or 12 mo of age. Thus, the LH response to buserelin provided a clearer discriminator between the 2 FertBV groups than the Kiss agonist used in this study, indicating that the difference between the 2 groups most likely resides within the pituitary gonadotropes. However, the data suggest that no difference exists in the ability to release $\mathrm{GnRH}$ in response to a given level of Kiss. Further work focused on the subcellular function of pituitary gonadotropes in prepubertal heifers may elucidate the mechanism to a greater extent.

At 12 mo of age, no significant differences were detected in the LH or FSH response to either Kiss or buserelin between FertBV groups, but these data are confounded by the heifers' proximity to puberty, with many having reached puberty by this point. Although plasma $\mathrm{P} 4$ data indicated that none of the heifers were displaying luteal activity (plasma P4 concentrations $<1 \mathrm{ng} / \mathrm{mL}$ ) before the 10-mo challenge, suggesting all heifers were prepubertal, more POS than NEG FertBV heifers ovulated in response to the challenges at this age. As we expected more variation in pubertal status at 10 mo, we implemented a prechallenge regimen to ensure all heifers had exposure to P4. Despite this additional intervention, significant differences were detectable in the $\mathrm{LH}$ response to buserelin between FertBV groups. Including P4 devices in the experiment design added complexity, which was thought necessary for control of P4 exposure. This approach would not be required where challenges occur at an earlier age, or where the number of animals in the study is less restricted, allowing the analysis to account for $\mathrm{P} 4$. In contrast, significantly more POS than NEG heifers had luteal activity indicative of reaching puberty before the challenges at 12 mo of age, but nearly all heifers ovulated in response to the challenges at this age. Although many heifers had not reached puberty before the 12-mo challenge, their proximity to puberty

Table 4. Experiment 2: Area under the curve (AUC), peak concentration (Cmax), and time from injection to peak concentration (Tmax) for the plasma concentrations of FSH following i.v. injection of either kisspeptin (4 $\mu \mathrm{g} / \mathrm{kg}$ of BW) or buserelin (10 $\mathrm{ng} / \mathrm{kg}$ of BW) in dairy heifers with negative (NEG) or positive (POS) fertility breeding values (FertBV) at 10 and 12 mo of age ${ }^{1}$

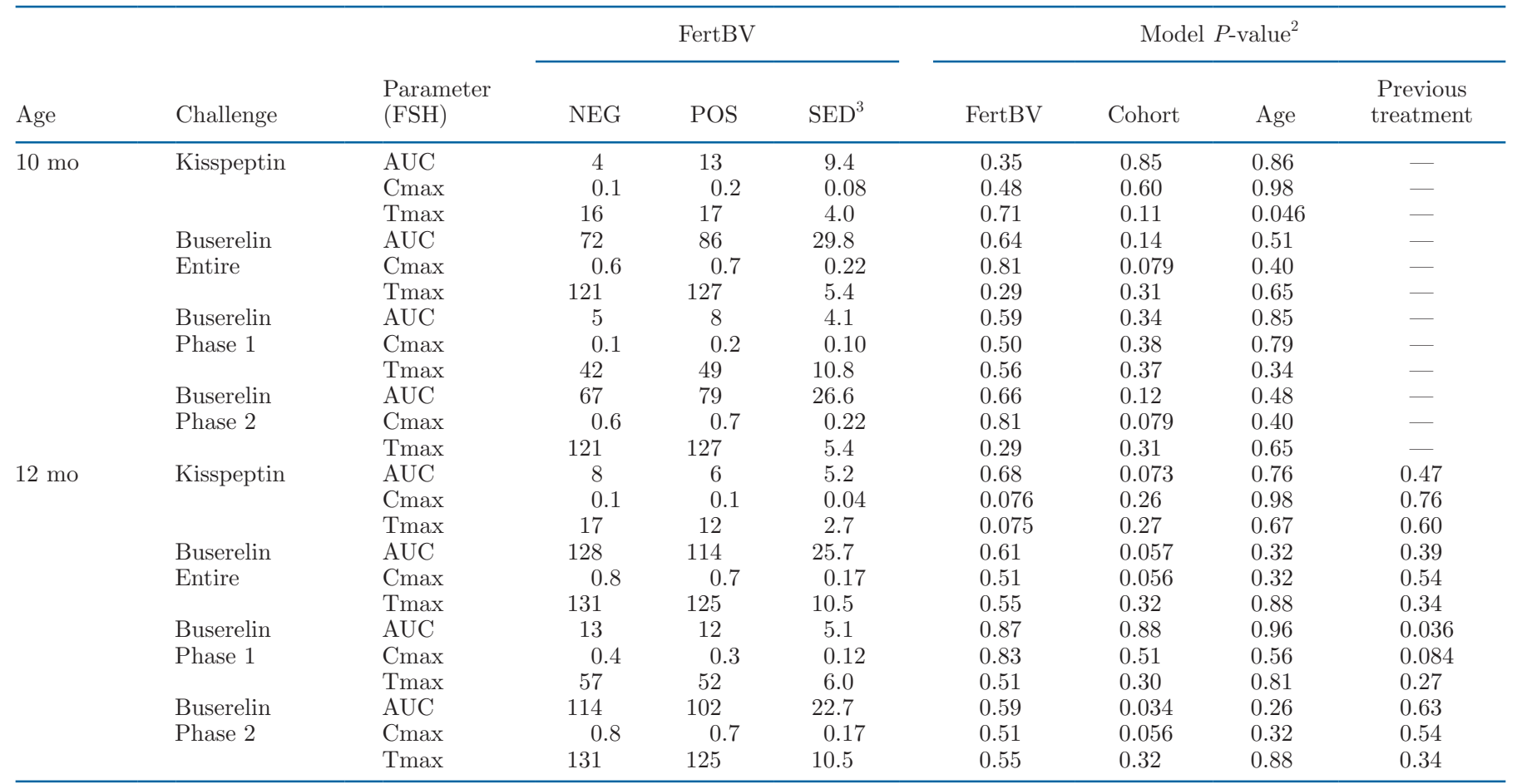

${ }^{1}$ For the buserelin challenge, results are presented for the entire response (injection to +300 min), phase 1 (injection to +60 min), and phase 2 $(+60$ to $+300 \mathrm{~min})$.

${ }^{2} P$-values for cohort indicate whether there was a significant effect of the cohort in which the animals were challenged. $P$-values for age indicate whether there is a significant linear effect of animals actual age at 10 mo. $P$-values for previous treatment indicate whether the treatment the animal received at 10 mo was significant (only relevant for the 12-mo challenge).

${ }^{3} \mathrm{SED}=$ standard error of the difference. 

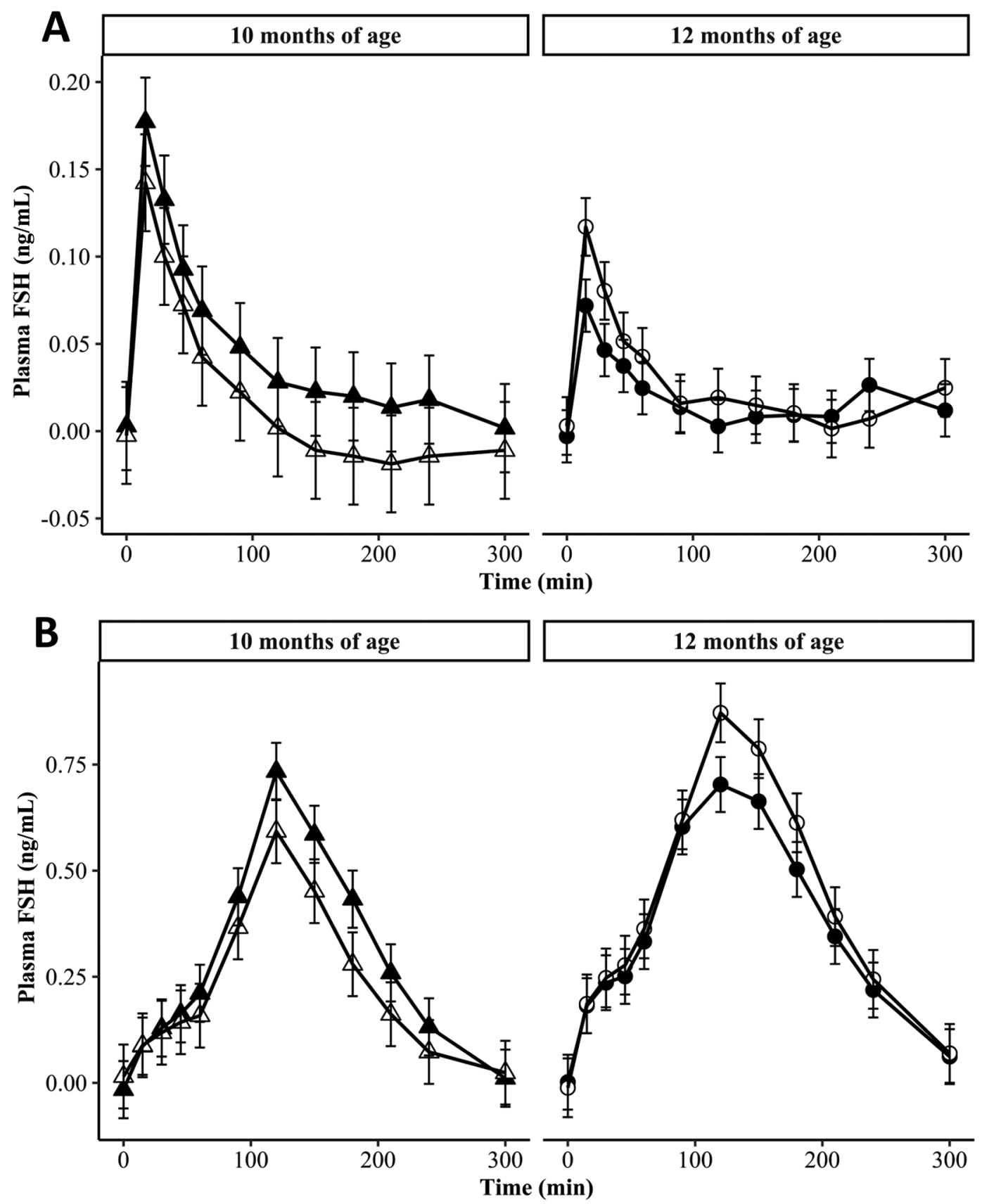

Figure 4. Least squares means $( \pm \mathrm{SEM})$ of plasma FSH concentrations following i.v. injection of either $(\mathrm{A}) \mathrm{kisspeptin}(4 \mu \mathrm{g} / \mathrm{kg}$ of BW) or $(\mathrm{B})$ buserelin $(10 \mathrm{ng} / \mathrm{kg}$ of BW) in heifers with positive (filled) or negative (unfilled) fertility breeding values at $10(\Delta)$ and $12(\mathrm{O})$ months of age.

was so close that the stimulation from the challenges was enough to induce puberty. This means that the heifers were characteristically postpubertal at the time of the 12-mo challenge, and hence the differences in the response to buserelin between FertBV groups were no longer evident at this age. Together, the results of the 10- and 12-mo challenges indicate that the HPG axis of the NEG heifers differs compared with that of the POS heifers, specifically, in the gonadotropin response to a GnRH agonist.

The reason for the reduced function of the HPG axis in the NEG heifers is not apparent but may be due to reduced pituitary gonadotrope function in NEG relative to POS FertBV heifers, among other factors. It seems unlikely to be due to inherent differences in the function of GnRH neurons in the hypothalamus, because 
Table 5. Percentages of dairy heifers with negative (NEG) or positive (POS) fertility breeding values (FertBV) with plasma progesterone concentrations indicative of luteal activity (plasma progesterone concentrations $>1 \mathrm{ng} / \mathrm{mL}$ ) $7 \mathrm{~d}$ pre- and 7 to $21 \mathrm{~d}$ postchallenge; proportions of heifers given in parentheses ${ }^{1}$

\begin{tabular}{|c|c|c|c|c|c|}
\hline \multirow[b]{2}{*}{ FertBV } & \multirow[b]{2}{*}{ Treatment } & \multicolumn{2}{|c|}{10 mo of age } & \multicolumn{2}{|c|}{12 mo of age } \\
\hline & & Prechallenge & Postchallenge & Prechallenge & Postchallenge \\
\hline POS & $\begin{array}{l}\text { Buserelin } \\
\text { Kisspeptin }\end{array}$ & $\begin{array}{c}0 \% \\
(0 / 11) \\
0 \% \\
(0 / 11)\end{array}$ & $\begin{array}{l}82 \% \\
(9 / 11) \\
45 \% \\
(5 / 11)\end{array}$ & $\begin{array}{l}50 \% \\
(5 / 10) \\
64 \% \\
(7 / 11)\end{array}$ & $\begin{array}{c}100 \% \\
(10 / 10) \\
91 \% \\
(10 / 11)\end{array}$ \\
\hline
\end{tabular}

${ }^{1}$ The challenges consisted of i.v. injection of either kisspeptin $(4 \mu \mathrm{g} / \mathrm{kg}$ of BW) or buserelin $(10 \mathrm{ng} / \mathrm{kg}$ of BW) at 10 and $12 \mathrm{mo}$ of age. The main effects of logistic regression on these data indicated that the percentage of heifers displaying luteal activity was more prevalent in POS than in NEG heifers $(P<0.001)$; greater at $12 \mathrm{mo}$ of age than at $10 \mathrm{mo}$ of age $(P<0.001)$; greater for those challenged with buserelin than for those challenged with kisspeptin $(P=0.029)$; and greater post-challenge than prechallenge $(P<0.001)$.

no differences were detectable in the response to Kiss between the POS and NEG FertBV heifers. Kisspeptin drives pulsatile GnRH secretion, and the response in terms of LH secretion (which reflects $\mathrm{GnRH}$ ) increases as calves progress toward puberty (Nakada et al., 2002; Alamilla Rodríguez et al., 2017). The number of Kiss cells in the caudal region of the arcuate nucleus increases during puberty in sheep (Li et al., 2020), so the timing of this neuroendocrine event could be a factor in the difference in age at puberty in POS and NEG cows. Thus, if less Kiss is produced in NEG heifers than in POS heifers in the prepubertal period, this might affect endogenous GnRH and LH secretion. The prepubertal period is characterized by enhanced negative feedback effects of estrogen on the $\mathrm{GnRH} /$ gonadotropin axis (Kinder et al., 1995), and data from a range of species indicate that such feedback is relayed to $\mathrm{GnRH}$ neurons via Kiss neurons (Clarke, 2011; Clarke et al., 2012). Accordingly, detailed longitudinal analysis of the negative feedback effect of estrogen and the function of Kiss neurons in the hypothalamus of prepubertal heifers would be required to address these points.

Collectively, our results and those of Meier et al. (2021b) indicate that genetic selection for calving- and mating-based traits using the FertBV is reflected in prepubertal response to a $\mathrm{GnRH}$ agonist. The precise timing of puberty can be difficult to assess in the large number of animals required for genetic evaluation. The requirement for monthly blood P4 testing, ovarian ultrasonography, or behavioral observations of estrus for heifers on a large scale can be logistically prohibitive. An alternative approach could be a buserelin challenge test to assess proximity to puberty in prepubertal animals based on their LH response, perhaps in just a single blood sample 120 min later (to coincide with Tmax). Potentially, the HPG axis could be tested younger than 10 mo of age, as Nakada et al. (2002) reported an LH response to GnRH as young as 1 mo of age in cattle. Further research would be needed to investigate the optimal age for this type of challenge. However, this approach has several limitations, whereby buserelin may (1) induce earlier puberty and thus confound subsequent outcome measures of submission and pregnancy rates; (2) result in issues with market access or consumer acceptance due to the use of hormones; and (3) still be relatively expensive and impractical for large numbers of animals. Instead, it could be more feasible to investigate HPG axis responsiveness or puberty timing in young bulls, provided these outcomes are well correlated with those in heifers. A greater understanding of the mechanisms driving the earlier HPG axis responsiveness and puberty onset in POS heifers may enable the development of practical early-life phenotyping that facilitates an increase in the rate of genetic gain for fertility traits.

\section{CONCLUSIONS}

In conclusion, we used 2 agonists to interrogate the status of the HPG axis in both the hypothalamus (Kiss) and pituitary (buserelin) glands. The most significant result was that the gonadotropes were more responsive to buserelin at 10 mo of age in POS than NEG heifers. Thus, it may be possible to identify animals with greater genetic merit for fertility by testing their HPG axis functionality before puberty. The association between FertBV and LH response to buserelin supports the hypothesis that mechanisms controlling the HPG axis that regulate the onset of puberty are more advanced in heifers with POS than NEG FertBV. 


\section{ACKNOWLEDGMENTS}

The authors acknowledge the invaluable support of the DairyNZ (Hamilton, New Zealand) technical and farm teams who supported the data collection for this study. We particularly thank Jenny Brown (DairyNZ) for conducting the plasma P4 assays. The LH and FSH assays were conducted by Alexandra Rao at Monash University, Melbourne, Australia. This work was funded by New Zealand dairy farmers through DairyNZ Incorporated, with matched co-funding from the Ministry of Business, Innovation and Employment (DRCX1302; Wellington, New Zealand) and aligned funding from AgResearch (SSIF; Hamilton, New Zealand). Breeding worth and breeding values were obtained from New Zealand Animal Evaluation Limited (Hamilton) with permission kindly granted by Livestock Improvement Ltd. (Hamilton, New Zealand). The authors have not stated any conflicts of interest.

\section{REFERENCES}

Alamilla Rodríguez, M., R. C. Calderón Robles, J. V. Rosete Fernández, K. Rodríguez Hernández, H. R. Vera Ávila, J. A. Arreguín Arévalo, T. M. Nett, C. G. Gutiérrez Aguilar, E. González Padilla, M. Gómez-Chavarín, and A. Villa Godoy. 2017. Kisspeptin in prepubertal heifers. I Effects of age on the response of LH, FSH and GH to kisspeptin-10 and its association with IGF-I, leptin and estradiol. Rev. Mex. Cienc. Pecu. 8:375-385. https://doi.org/10 $.22319 /$ rmcp.v8i4.4644.

Berry, D. P., E. Wall, and J. E. Pryce. 2014. Genetics and genomics of reproductive performance in dairy and beef cattle. Animal 8(Suppl. 1):105-121. https://doi.org/10.1017/S1751731114000743.

Clarke, I. J. 2011. Control of GnRH secretion: one step back. Front. Neuroendocrinol. 32:367-375. https://doi.org/10.1016/j.yfrne 2011.01.001.

Clarke, I. J. 2014. Interface between metabolic balance and reproduction in ruminants: Focus on the hypothalamus and pituitary. Horm. Behav. 66:15-40. https://doi.org/10.1016/j.yhbeh.2014.02 .005 .

Clarke, I. J., R. Campbell, J. T. Smith, V. Prevot, and S. Wray. 2012. Chapter 9: Neuroendocrine control of reproduction. Pages 197-235 in Handbook of Neuroendocrinology. G. Fink, D. W. Pfaff, and J. E. Levine, ed. Academic Press.

Clarke, I. J., and J. T. Cummins. 1985. GnRH pulse frequency determines LH pulse amplitude by altering the amount of releasable LH in the pituitary glands of ewes. Reproduction 73:425-431. https:// doi.org/10.1530/jrf.0.0730425.

DairyNZ. 2016. Description of national genetic evaluation systems: Female fertility. Accessed Jul. 23, 2020. https://www.dairynz.co.nz/ animal/animal-evaluation/interpreting-the-info/breeding-values/.

Egger-Danner, C., J. B. Cole, J. E. Pryce, N. Gengler, B. Heringstad, A. Bradley, and K. F. Stock. 2015. Invited review: Overview of new traits and phenotyping strategies in dairy cattle with a focus on functional traits. Animal 9:191-207. https://doi.org/10.1017/ S1751731114002614.

Esslemont, R. J., M. A. Kossaibati, and J. Allcock. 2001. Economics of fertility in dairy cows. BSAP Occasional Publication 26:19-29. https://doi.org/10.1017/S0263967X00033565.

Ezzat, A., A. Pereira, and I. J. Clarke. 2015. Kisspeptin is a component of the pulse generator for $\mathrm{GnRH}$ secretion in female sheep but not the pulse generator. Endocrinology 156:1828-1837. https://doi .org/10.1210/en.2014-1756.
Ezzat Ahmed, A., H. Saito, T. Sawada, T. Yaegashi, T. Yamashita, T. Hirata, K. Sawai, and T. Hashizume. 2009. Characteristics of the stimulatory effect of kisspeptin-10 on the secretion of luteinizing hormone, follicle-stimulating hormone and growth hormone in prepubertal male and female cattle. J. Reprod. Dev. 55:650-654. https://doi.org/10.1262/jrd.20255.

Franceschini, I., D. Lomet, M. Cateau, G. Delsol, Y. Tillet, and A. Caraty. 2006. Kisspeptin immunoreactive cells of the ovine preoptic area and arcuate nucleus co-express estrogen receptor alpha. Neurosci. Lett. 401:225-230. https://doi.org/10.1016/j.neulet.2006 .03.039.

Herbison, A. E., J. E. Robinson, and D. C. Skinner. 1993. Distribution of estrogen receptor-immunoreactive cells in the preoptic area of the ewe: Co-localization with glutamic acid decarboxylase but not luteinizing hormone-releasing hormone. Neuroendocrinology 57:751-759. https://doi.org/10.1159/000126433.

Johnston, D. J., S. A. Barwick, N. J. Corbet, G. Fordyce, R. G. Holroyd, P. J. Williams, and H. M. Burrow. 2009. Genetics of heifer puberty in two tropical beef genotypes in northern Australia and associations with heifer- and steer-production traits. Anim. Prod. Sci. 49:399-412. https://doi.org/10.1071/EA08276.

Kadokawa, H., M. Matsui, K. Hayashi, N. Matsunaga, C. Kawashima, T. Shimizu, K. Kida, and A. Miyamoto. 2008. Peripheral administration of kisspeptin-10 increases plasma concentrations of GH as well as LH in prepubertal Holstein heifers. J. Endocrinol. 196:331334. https://doi.org/10.1677/JOE-07-0504.

Kerslake, J. I., P. R. Amer, P. L. O'Neill, S. L. Wong, J. R. Roche, and C. V. C. Phyn. 2018. Economic costs of recorded reasons for cow mortality and culling in a pasture-based dairy industry. J. Dairy Sci. 101:1795-1803. https://doi.org/10.3168/jds.2017-13124.

Kinder, J. E., E. G. Bergfeld, M. E. Wehrman, K. E. Peters, and F. N. Kojima. 1995. Endocrine basis for puberty in heifers and ewes. J. Reprod. Fertil. Suppl. 49:393-407.

Lehman, M. N., and F. J. Karsch. 1993. Do gonadotropin-releasing hormone, tyrosine hydroxylase-, and beta-endorphin-immunoreactive neurons contain estrogen receptors? A double-label immunocytochemical study in the Suffolk ewe. Endocrinology 133:887-895. https://doi.org/10.1210/endo.133.2.8102098.

Leonardi, C. E. P., F. C. F. Dias, G. P. Adams, and J. Singh. 2018. Effect of kisspeptin-10 on plasma luteinizing hormone concentrations and follicular dynamics during the luteal phase in cattle. Theriogenology 119:268-274. https://doi.org/10.1016/j.theriogenology .2018.06.023.

Li, Q., J. T. Smith, B. Henry, A. Rao, A. Pereira, and I. J. Clarke. 2020. Expression of genes for kisspeptin (KISS1), neurokinin B (TAC3), prodynorphin $(P D Y N)$, and gonadotropin inhibitory hormone $(R F R P)$ across natural puberty in ewes. Physiol. Rep. 8:e14399. https://doi.org/10.14814/phy2.14399.

Macedo, G. G., R. D. Mingoti, E. O. S. Batista, B. M. Monteiro, L. M. Vieira, R. V. Barletta, M. C. Wiltbank, G. P. Nogueira, F. P. Rennó, J. R. Maio, and P. S. Baruselli. 2019. Profile of LH release in response to intramuscular treatment with kisspeptin in Bos indicus and Bos taurus prepubertal heifers. Theriogenology 125:64-70. https://doi.org/10.1016/j.theriogenology.2018.10.011.

Meier, S., B. Kuhn-Sherlock, P. A. Amer, J. R. Roche, and C. R. Burke. 2021a. Positive genetic merit for fertility traits is associated with superior reproductive performance in pasture-based dairy cows with seasonal calving. J. Dairy Sci. 104:10382-10398. https:/ /doi.org/10.3168/jds.2021-20195.

Meier, S., L. R. McNaughton, R. Handcock, P. R. Amer, P. R. Beatson, J. R. Bryant, K. G. Dodds, R. Spelman, J. R. Roche, and C. R. Burke. 2021b. Heifers with positive genetic merit for fertility traits reach puberty earlier and have a greater pregnancy rate than heifers with negative genetic merit for fertility traits. J. Dairy Sci. 104:3707-3721. https://doi.org/10.3168/jds.2020-19155.

Mialon, M.-M., G. Renand, D. Krauss, and F. Ménissier. 2000. Genetic variability of the length of postpartum anoestrus in Charolais cows and its relationship with age at puberty. Genet. Sel. Evol. 32:403414. https://doi.org/10.1186/1297-9686-32-4-403.

Ministry for Primary Industries. 1999. New Zealand Animal Welfare Act. Part 6: Use of animals in research, testing and teaching. Ac- 
cessed Sep. 22, 2021. http://www.legislation.govt.nz/act/public/ 1999/0142/latest/DLM50499.html?search=sw_096be8ed817c720c Part+6_25_se\&p=1.

Morris, C. A., and S. M. Hickey. 2004. Heritability of puberty traits in dairy heifers in commercial herds. Pages $115-117$ in N. Z. Soc. Anim. Prod. Proc. Vol. 64. New Zealand Society of Animal Production.

Morris, C. A., J. A. Wilson, G. L. Bennett, N. G. Cullen, S. M. Hickey, and J. C. Hunter. 2000. Genetic parameters for growth, puberty, and beef cow reproductive traits in a puberty selection experiment. N. Z. J. Agric. Res. 43:83-91. https://doi.org/10.1080/00288233 .2000 .9513411

Nakada, K., Y. Ishikawa, T. Nakao, and Y. Sawamukai. 2002. Changes in responses to $\mathrm{GnRH}$ on luteinizing hormone and follicle stimulating hormone secretion in prepubertal heifers. J. Reprod. Dev. 48:545-551. https://doi.org/10.1262/jrd.48.545.

Otto, J. R., B. S. Malau-Aduli, A. Rao, I. J. Clarke, and A. E. O. Malau-Aduli. 2014. Effect of incremental levels of crude degummed canola oil on milk progesterone, plasma luteinizing and follicle stimulating hormones of primiparous Holstein-Friesian cows in a pasture-based system. Int. J. Vet. Sci. Med. 2:122-129. https://doi .org/10.1016/j.ijvsm.2014.10.001.

Pryce, J. E., R. Woolaston, D. P. Berry, E. Wall, M. Winters, R. Butler, and M. Shaffer. 2014. World trends in dairy cow fertility. Page 154 in Proc. World Congress Genet. Appl. Livest. Prod., Vancouver, Canada. Am. Soc. Anim. Sci.

Scott, C. J., J. L. Rose, A. J. Gunn, and B. M. McGrath. 2018. Kisspeptin and the regulation of the reproductive axis in domestic animals. J. Endocrinol. 240:R1-R16. https://doi.org/10.1530/JOE $-18-0485$.

Shalloo, L., A. Cromie, and N. McHugh. 2014. Effect of fertility on the economics of pasture-based dairy systems. Animal 8:222-231. https://doi.org/10.1017/S1751731114000615.

Smith, J. T., Q. Li, K. S. Yap, M. Shahab, A. K. Roseweir, R. P. Millar, and I. J. Clarke. 2011. Kisspeptin is essential for the full preovulatory LH surge and stimulates GnRH release from the isolated ovine median eminence. Endocrinology 152:1001-1012. https://doi .org/10.1210/en.2010-1225.

von Keyserlingk, M. A. G., N. P. Martin, E. Kebreab, K. F. Knowlton, R. J. Grant, M. Stephenson, C. J. Sniffen, J. P. Harner III, A. D. Wright, and S. I. Smith. 2013. Invited review: Sustainability of the US dairy industry. J. Dairy Sci. 96:5405-5425. https://doi.org/10 .3168/jds.2012-6354

\section{ORCIDS}

H. E. Flay () https://orcid.org/0000-0002-0595-807X

C. B. Reed 자 https://orcid.org/0000-0001-7010-185X

B. Kuhn-Sherlock @ https://orcid.org/0000-0002-1890-0301

C. V. C. Phyn @ https://orcid.org/0000-0002-4912-4069

C. R. Burke @ https://orcid.org/0000-0003-3868-8675

S. Meier (1) https://orcid.org/0000-0002-4386-7734

I. J. Clarke @ https://orcid.org/0000-0002-6613-2757 